\title{
Plagiarism exposed in Romanian grant applications
}

\section{More than a dozen applications suspected of plagiarism.}

\section{Alison Abbott}

07 November 2012

Earlier this year, Nature exposed a series of plagiarism scandals in Romania that implicated the country's prime minister Victor Ponta, a former research minister and university leaders. Now evidence is emerging of plagiarism in applications for public grant money.

None of the suspect applications were funded. But some Romanian scientists fear that the affair is being swept under the carpet by the ministry of research, which has not pursued concerns and in September proposed new rules to reduce oversight of grant decisions.

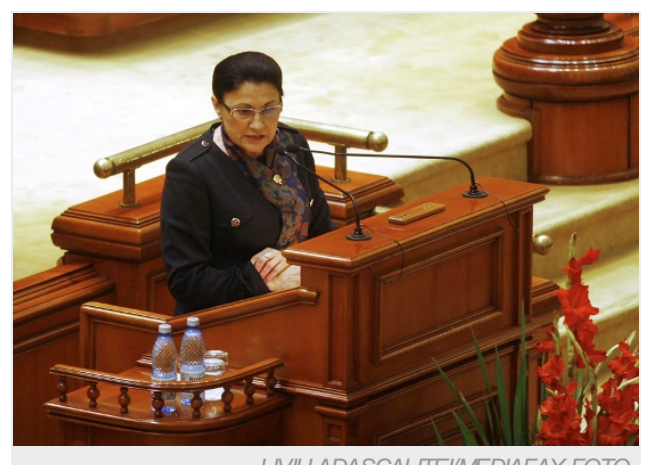

LIVIU ADASCALITEVMEDIAFAX FOTO

Ecaterina Andronescu, Romania's research minister, has not pushed forward investigations into scientific misconduct in grant applications.

Grant administrators were first alerted to the suspicious applications in February, and 14 suspect cases - each involving nearly half a million euros — were listed on a government website on 22 May, shortly after Ponta took office. Although misconduct cases are supposed to be investigated and resolved within 90 days of being brought to the attention of the national ethics council, most remain unresolved. The council confirmed plagiarism in four cases this spring, but was not given the go ahead to publish its findings on a fifth by the research ministry's legal department. Ponta dismantled the council on 8 June, before it could complete its investigation of the others. The council had been poised to rule on plagiarism charges against former research minister loan Mang.

But today the watchdog website Integru.org, which publishes evidence of plagiarism by scientists in Romania along with comments from international experts, has posted its analysis of that fifth application, which was leaked to a journalist there. The application requested $€ 465,000$ (US\$593,000) for a project involving "optical wireless-based networks for broadband multi-services applications", which it called OWHAN. It proposed a collaboration between eight scientists at three universities, with the National Research Communications Institute (INSCC) as coordinating institution.

Integru's examination, however, reports that nearly all of the application was copied from five different sources. lan Wassell, a communications engineer at the University of Cambridge, UK, and one of the four international experts who examined the application for Integru, commented that in his view it was "the most blatant case of plagiarism [he has] encountered." Other reviews, similarly scathing, criticised the application's justification for the large amount of money requested and the fuzziness of its explanation of how it would be distributed.

"The government should attend to such conduct, which is an attempt to steal public funds," says Dragos Ciuparu, a chemical engineer at the Petroleum-Gas University of Ploieşti and former president of Romania's National Authority for Scientific Research.

Grant administrators had declined an earlier Freedom of Information request from Nature to see the application on the grounds that it was not in the public interest because it was not funded, and it remained "at the level of [a] research idea".

Chemist Ecaterina Andronescu signed the OWHAN application in her role as a rector at one of the participating universities - the Polytechnic University of Bucharest - a position she held until April this year. In July she became Romania's research minister. She declined to directly answer questions about why she had not followed up on the investigations into alleged misconduct in either of her capacities. Instead, she told Nature in an e-mail that she had no personal responsibility for the stalled investigations but she is "concerned about such misconduct in applying for research [grants]".

The OWHAN project manager was Florin Constantinescu, an electrical engineer at the Polytechnic University of Bucharest, although he gave his affiliation as the INSCC in the application. On 6 May the INSCC ethics committee published its own report saying that one of the other OWHAN participants, Radu Dragomir, an electronics engineer at the INSCC, admitted sole responsibility for writing the 
grant. Constantinescu told Nature that he neither wrote nor read the application he signed, and that Radu's acceptance of full blame exonerates him.

Some scientists in Romania worry that the government is trying to water down safeguards against plagiarism and other types of misconduct such as conflicts of interest. A proposal published on the ministry website on 19 September would, for example, exclude the requirement for foreign oversight of grant applications. The suspect applications were caught because the Joint Applied Research Projects (PCCA) programme requires two-thirds of the evaluators to be located outside the country, a provision for such large grants intended to prevent collusion within the small Romanian scientific community. A source close to the ministry says that the proposal is now being changed to reflect the scientists' concerns.

Although Romania's new ethics committee, set up in June, has not followed up on the remaining suspect PCCA applications, it has reported on the plagiarism charges against three powerful professors at the University of Medicine and Pharmacy of Târgu Mureș. The previous incarnation of the ethics committee had said the case involved "clear plagiarism". But on 1 November the new committee published a report clearing Klara Brânzaniuc, Constantin Copotoiu and Leonard Azamfirei of misconduct on the grounds that they were apparently unaware that they had been included as authors on papers published by the university's journal Acta Medica Marisiensis. One student co-author received a 12-month ban on applying for an academic post and another a written warning for including their department heads as authors.

Nature I doi:10.1038/nature.2012.11758 